\title{
Prothymosin Alpha Location in the Proliferative Compartments of the Digestive Tract Epithelium
}

\author{
Rosalía Gallego $^{1}$, Tomas Garcia-Caballero ${ }^{1}$, Elena Roson ${ }^{1}$, Maximo Fraga ${ }^{2}$, \\ Fernando Dominguez ${ }^{3}$ and Andres Beiras ${ }^{1}$ \\ ${ }^{1}$ Departments of Morphological Sciences, ${ }^{2}$ Pathology and ${ }^{3}$ Physiology, Faculty of Medicine, Santiago de \\ Compostela, Spain
}

Received for publication October 20, 1997 and in revised form December 16, 1997 and re-revised form August 7, 1998

\begin{abstract}
Prothymosin alpha is a polypeptide whose function is still a matter of debate. The present paper represents the first morphological description of the prothymosin alpha distribution in the human and rat digestive tract tissues using immunohistochemical techniques. In these epithelia prothymosin alpha immunostaining was localized in the nuclei of the proliferating cells, e.g. in the basal layer cells of the oesophagus, cells of the isthmus and the neck of the gastric glands, and crypt cells in the small and large intestines. At the ultrastructural level, prothymosin alpha immunolabelling was evident in the nucleus, being confined to euchromatin. The present data indicates

that prothymosin alpha expression in the digestive tract epithelia is associated with proliferating cell populations. In agreement with this hypothesis, we found that the patterns of distribution of prothymosin alpha and proliferating cell nuclear antigen were similar. The distribution of prothymosin immunoreactivity was also similar to that obtained for bromodeoxyuridine when the animal was sacrificed $12 \mathrm{hr}$ after injection. The finding that intracellular distribution of the prothymosin alpha in the digestive tract epithelia is identical to that found in other tissues supports the idea that prothymosin alpha must play a universal role in proliferating cells.
\end{abstract}

Key words: Prothymosin, Cell proliferation, Digestive tract

\section{Introduction}

Prothymosin alpha (ProT) is an acidic polypeptide originally isolated from the rat thymus [17]. Although it has been known to be associated with the regulation of cellular immunity [21,35], a growing body of evidence suggests that ProT plays an essential role in cell division. ProT shows a wide distribution in many tissues such as thymus, spleen, lung, kidney, liver and brain [6, 18]. ProT mRNA was demonstrated in actively proliferating cells, but not in resting cells [8]. ProT and its mRNA were significantly higher in foetuses and newborns than in adult rats $[5,10]$, and in human thymus the content of ProT decreases with age [29]. Moreover, ProT antisense oligomers inhibit myeloma cell division [27], and ProT gene transcription is regulated by the proto-oncogene myc that has been implicated in cell proliferation [7, 13, 30]. Vareli et al. [31] demonstrated that transcription activating

Correspondence to: Dr. Rosalía Gallego, Departamento de Ciencias Morfológicas, Facultad de Medicina, San Francisco s/n, E-15705 Santiago de Compostela, España. factor E2F was also a strong positive regulator of the ProT gene and suggested that ProT was involved in proliferation checkpoints of the cell cycle. ProT was also identified as a tumour associated gene, and a correlation between ProT and c-myc mRNA levels was shown in human colon cancer [22], while elevated protein levels have been measured in breast and intestinal malignant tissues [4, 29].

ProT immunoreactivity was previously demonstrated in proliferating cells of lymphoid $[11,23]$ and non lymphoid tissues $[9,12,24,25]$, but there are no previous reports of ProT distribution in human and rat digestive tissue. The aim of the present work was to study the expression of ProT in human and rat digestive tract epithelia where proliferative compartments are well known. Moreover, a comparative study was done between ProT and proliferating cell nuclear antigen (PCNA), a wellestablished proliferation marker [16, 32]. The findings were also compared with the results obtained with techniques based on 5-bromo-2'-deoxyuridine (BrdUrd) incorporation during DNA synthesis [14]. Immunoelectron microscopic procedures were also performed to determine the exact intracellular localization of ProT. 


\section{Materials and Methods}

\section{Light microscopic immunostaining}

Human and rat oesophagus, stomach (body), and small (ileum) and large (colon) intestines were used for immunohistochemistry. Sprague-Dawley male rats (weighing about $250 \mathrm{~g}, \mathrm{n}=6$ ) were killed by a lethal injection of sodium pentothal. Animals were always sacrificed in the early morning, to ensure standard parameters with respect to the circadian rhythm of the mitotic index of the digestive tract epithelia, the peak occurring during the first half of the diurnal phase [1]. Human material $(n=6$ for each organ) was obtained from healthy margins of surgical specimens. Samples were immersion-fixed in 10\% buffered formalin, dehydrated and embedded in paraffin.

The avidin-biotin-peroxidase complex (ABC) procedure of Hsu et al. [19] was employed. Endogenous peroxidase was blocked with $0.3 \%$ hydrogen peroxide in phosphate-buffered saline pH 7.4 (PBS, $0.1 \mathrm{M}$ phosphate buffer containing $0.15 \mathrm{M} \mathrm{NaCl}$ ). Four $\mu$ m-thick sections were consecutively incubated in: 1) normal goat serum (NGS) (Dakopatts, Glostrup, Denmark) diluted 1:10 in PBS for $30 \mathrm{~min}$. This step was only done when the primary antibody was polyclonal; 2) $0.1 \mathrm{mg} / \mathrm{ml} \mathrm{IgG} \mathrm{fraction}$ purified from polyclonal rabbit anti-ProT antiserum (polyclonal antibodies to Prothymosin alpha were made by injecting rabbits with synthetic thymosin alpha-1 conjugated to keyhole limphet hemocyanin, Calbiochem, La Jolla, CA) or monoclonal mouse antibody against proliferating cell nuclear antigen (PCNA, PC10 clone Dakopatts) at a dilution $1: 10$, both for $1 \mathrm{hr} ; 3$ ) biotinylated goat anti-rabbit immunoglobulins (Dakopatts) when primary antiserum anti-ProT was used; or biotinylated rabbit anti-mouse immunoglobulins (Dakopatts) when the primary antibody was anti-PCNA; both at a dilution of $1: 400$, for $30 \mathrm{~min}$; 4) avidin-biotin-peroxidase complex (Vectastain Elite Kit, Vector, Burlingame, CA) prepared according to the protocol provided by the manufacturer, for $30 \mathrm{~min}$; and 5$) 0.06 \%(\mathrm{w} / \mathrm{v})$ solution of 3,3' diaminobenzidine-tetrahydrochloride (Sigma Chemical Co., St Louis, MO) with $0.003 \%$ (v/v) hydrogen peroxide for $5 \mathrm{~min}$. Between steps, the sections were washed with PBS and, after step 5, with distilled water. All dilutions were made in PBS. The sections were optionally counterstained with $0.2 \%$ methyl green for 2 min. To compare ProT and PCNA immunoreactivity, consecutive sections were respectively immunostained for ProT and PCNA. Controls were performed by either preadsorbing the non commercial anti-ProT antibody with synthetic thymosin alpha 1 (overnight at $4^{\circ} \mathrm{C}$ ) or omitting other essential steps of the reaction. In both cases no immunoreactivity was seen.

\section{Incorporation and immunostaining of BrdUrd}

Incorporation of BrdUrd in vivo was achieved by $1 \mathrm{mg}$ of BrdUrd intravenous injection per rat $(250 \mathrm{~g})$. The rats were killed $1 \mathrm{hr}(\mathrm{n}=2)$ and $12 \mathrm{hr}(\mathrm{n}=2)$ after the
BrdUrd injection and samples of small intestine were fixed, sectioned and embedded as described above. Prior to immunoreaction the sections were treated with $0.1 \%$ trypsin in $0.1 \%$ calcium chloride (for $20 \mathrm{~min}$ at $37^{\circ} \mathrm{C}$ ) and $95 \%$ (v/v) formamide in $0.15 \mathrm{M}$ trisodium citrate for double stranded DNA denaturation (for $45 \mathrm{~min}$ at $70^{\circ} \mathrm{C}$ ). Immunostaining was performed in the same way as for PCNA, but the primary antibody employed was monoclonal mouse anti-BrdUrd (Dakopatts) at a dilution of $1: 10$ (for $1 \mathrm{hr}$ at room temperature) and a biotinylated anti-mouse immunoglobulin antibody raised in rabbits (Dakopatts) was used at a dilution of $1: 400$ (for $30 \mathrm{~min}$ at room temperature).

\section{Ultrastructural immunocytochemistry}

For immunolabelling at the electron microscopic level, adult rats $(n=5)$ were perfused with $2 \%$ paraformaldehyde and $0.2 \%$ glutaraldehyde in $0.1 \mathrm{M}$ sodium phosphate buffer (pH 7.4). Oesophagus, stomach, and small and large intestines were excised and cut into small pieces, then immersed in the same fixative for $2 \mathrm{hr}$ at $4^{\circ} \mathrm{C}$. After washing in phosphate buffer, the specimens were dehydrated in an ethanol series and embedded in LR White (The London Resin Co, Basingstoke, UK). Polymerization was done at $60^{\circ} \mathrm{C}$ for $8 \mathrm{hr}$, avoiding contact between the resin and oxygen. Ultrathin sections ( $60 \mathrm{~nm}$ thick) were collected on uncoated 300-mesh nickel grids. Labelling procedures were performed at room temperature using the next protocol: 1) NGS $1: 50$ in PBS containing $0.5 \%$ ovalbumin ( $5 \mathrm{~min}) ; 2$ ) IgG fraction from anti-ProT rabbit serum (overnight, at a concentration of $0.1 \mathrm{mg} / \mathrm{ml}$ in PBS containing 1\% ovalbumin); 3) PBS (twice for $5 \mathrm{~min}$ each); 4) $0.5 \%$ ovalbumin in $0.05 \mathrm{M}$ Tris- $\mathrm{HCl}, \mathrm{pH} 8.4$ $(5 \mathrm{~min}) ; 5) 10 \mathrm{~nm}$ gold conjugated goat-anti-rabbit IgG (Biocell, Cardiff, UK) diluted $1: 20$ in $0.05 \mathrm{M}$ Tris- $\mathrm{HCl}$, $\mathrm{pH} 7.4$, containing $1 \%$ ovalbumin $(1 \mathrm{hr}) ; 6) \quad 0.05 \mathrm{M}$ Tris-HCl pH 7.4 (5 min); and 7) distilled water (5 min). Contrast was produced using $2 \%$ uranyl acetate for $2 \mathrm{~min}$. Controls, performed in the same way as for immunohistochemistry at the light microscopic level, showed a negative reaction.

\section{Results}

In the oesophagus, lined by stratified squamous epithelium, ProT was demonstrated in the basal and suprabasal layer cells (Fig. 1). In the body of the stomach ProT was primarily expressed by cells located in the isthmus and the neck of the gastric glands (Fig. 2). ProT immunoreactivity was demonstrated in the small intestinal crypts (Fig. 3A). Serial sections immunostained for PCNA demonstrated a similar pattern of distribution (Fig. 3B). The large intestine also showed numerous ProT immunoreactive cells in the basal part of the crypts (Fig. 4). ProT immunoreactivity was found in the nuclei of interphase cells. Mitotic cells presented weak ProT immunostaining that was diffusely distributed in the 
cytoplasm (Fig. 5A, B). BrdUrd incorporation and immunostaining showed a lower number of immunoreactive cells in the proliferative compartment of intestinal crypts than ProT immunostaining when the animal was sacrificed one hour after BrdUrd injection. The number of BrdUrd immunoreactive cells twelve hours after BrdUrd injection was similar to that obtained for ProT (Fig. 6A-C).

The demonstration of ProT immunoreactivity at the ultrastructural level (Fig. 7) revealed the gold particles limited to the nuclei, the cytoplasms being negative. Immunolabelling was primarily found on the euchromatin. Nucleoli were predominantly negative, and only occasionally were gold particles seen in the pars amorpha.

\section{Discussion}

The results obtained in this study clearly showed that ProT immunoreactivity was localized in the nuclei of cells that belong to proliferative compartments of the digestive tract epithelia: e.g. the basal layer of the oesophageal stratified epithelium; the isthmus and neck cells of the gastric glands; the crypts of the small bowel and the basal half of the large intestinal crypts. ProT immunostaining distribution in the oesophagus was consistent with the previous demonstration of ProT in the basal layers of the stratified epithelium of the tonsils [11]. A similar result was noted by Dalakas et al. in the stratum germinativum of another stratified epithelium e.g. the epidermis [3]. Nearly all cells of the crypt of the small bowel were immunostained. The finding of ProT immunoreactive cells in the upper part of the small intestinal crypts may be explained by the rapid migration of these cells and the long half-life of the ProT protein; $24 \mathrm{hr}$ were required for ProT mRNA levels to be almost undetectable after serum deprivation [34]. A similar observation was reported for PCNA [26].

On the other hand, the comparison of results obtained with ProT and PCNA led us to support that ProT is also a proliferation marker. PCNA is a well known proliferation marker and widely used to evaluate cell proliferation in diagnostic histopathology $[20,28]$. Our results agree with those obtained by Sarraf et al. for PCNA (PC10 clone) studying gastrointestinal epithelia [26]. PCNA and also ProT immunoreactivities indicate the total growth fraction. PCNA [15] and ProT [34] expression was demonstrated during all steps of the cell cycle. ProT mRNA levels are invariant throughout the cell cycle [34] although it was reported that a peak of mRNA appears probably at the end of S/G2 phase of the cell cycle [31].

Recently it was found that ProT assessment in primary breast cancer can have diagnostic value [4] thus, opening the possibility that ProT could be used as a tumour proliferation marker. ProT levels were demonstrated to be higher in malignant that in normal tissues [4, 9, 29]. Moreover ProT mRNA is overexpressed in colon carcinoma compared with normal mucosa [22] and in hepatocellular carcinoma with regard to normal liver [33].

At the ultrastructural level ProT immunoreactivity is located in the euchromatin. Immunogold labelling differs from that obtained by Conteas et al. [2] who localized ProT immunolabelling over the condensed chromatin of IEC-6 cells. Our results concerning the immature small intestinal cells agree with the ProT nuclear distribution found in proliferating lymphoid cells from the tonsils and the adrenal cortex $[11,12]$. These results support the idea that the ProT distribution found here could be universal and, therefore, independent of the cell type studied.

In summary, we have found that in the digestive tract epithelia ProT and PCNA share a similar cellular distribution which coincides with the proliferative compartments. Although the physiological role of ProT remains uncertain, its nuclear distribution points to the fact that the proliferating nuclei must be the scenario for ProT functioning.

\section{Acknowledgments}

This work was partially supported by a grant from the Xunta de Galicia (XUGA 20811B97). The authors thank D. Fernandez-Roel and A. Vazquez Boquete for technical assistance.

Fig. 1. Rat oesophageal epithelium which shows ProT immunostaining in the nuclei of the basal and some suprabasal cells. $\times 275$.

Fig. 2. Rat gastric mucosa. ProT immunoreactive nuclei are mainly localized in the isthmus and the neck of the gastric glands. Methyl green counterstained. $\times 130$.

Fig. 3. A: Human small intestine immunostained for ProT in which the epithelial immunoreactive cells are mainly located in the crypts. In the lamina propria immunostained cells correspond to lymphocytes. B: Consecutive section immunostained for PCNA. The comparison with Fig. 3a shows that the distribution of immunoreactivity for both markers is similar. $\times 120$.

Fig. 4. Human large intestinal mucosa immunostained for ProT. Immunoreactive cells are mainly concentrated in the basal half of the intestinal crypts. Methyl green counterstained. $\times 150$.

Fig. 5. Micrographs corresponding to the same field were obtained from the bottom of human large bowel crypt. They show a mitotic figure with a weak ProT immunostaining in the cytoplasm (arrows). A was made prior to the counterstaining and $\mathbf{B}$ after counterstaining with methyl green to show the chromosomic mass. $\times 1000$.

Fig. 6. Duodenal epithelium immunostained for bromo-deoxiuridine of a rat sacrificed $1 \mathrm{hr}$ after the injection (A). Immunoreactive cells are placed at the base of the small intestinal crypt. In the rats with longer supervivence $(12 \mathrm{hr})$ after the injection, immunoreactive cells are placed not only at the base of intestinal crypt but also extended to the base of the villi (B). C corresponds to a semiserial section of the epithelia of B showing the similar distribution of ProT immunoreactive cells. $\times 150$. 

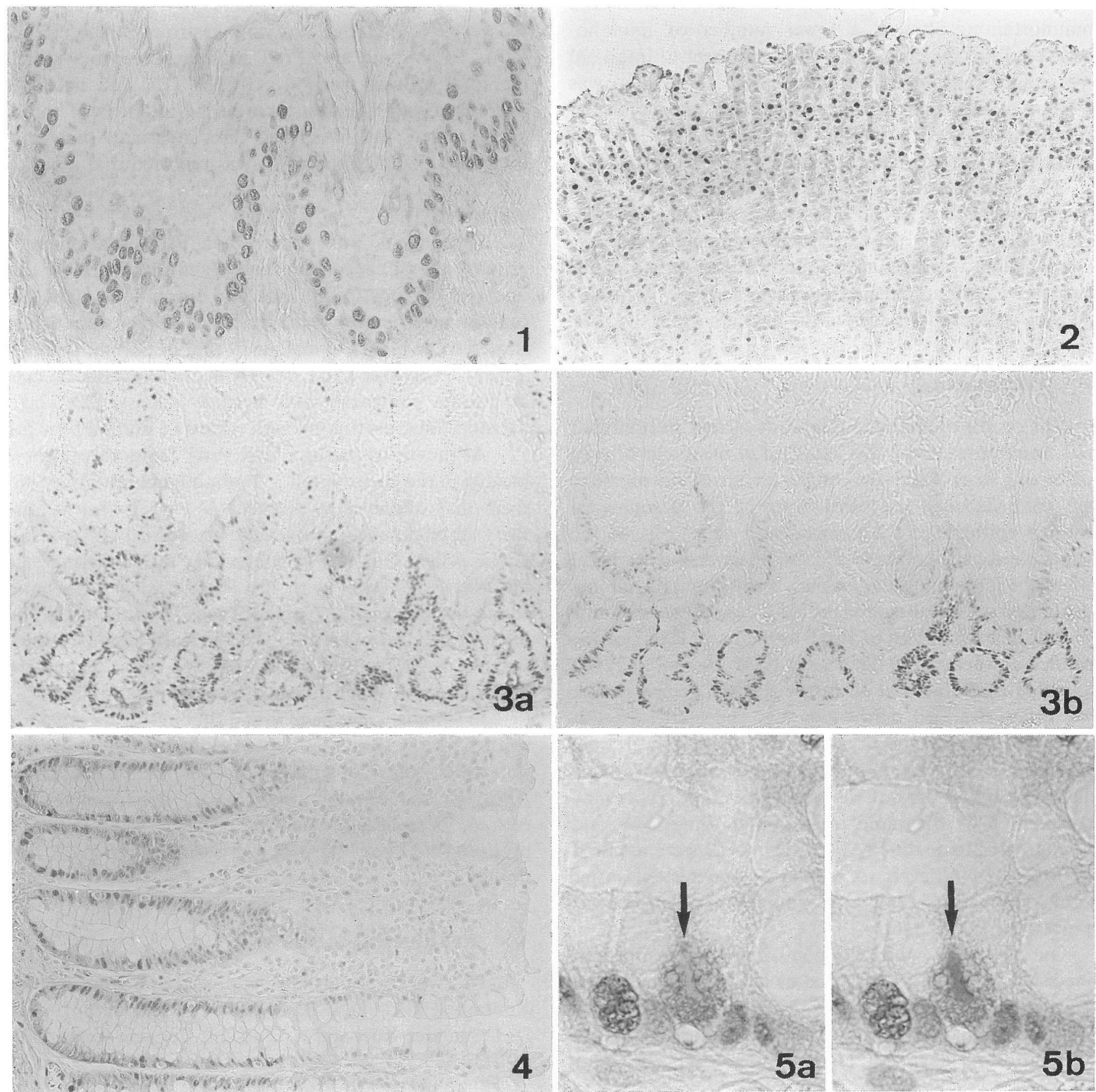

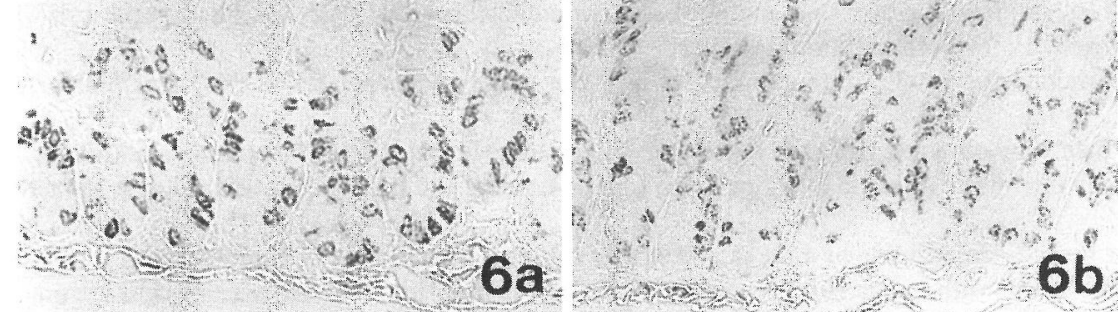

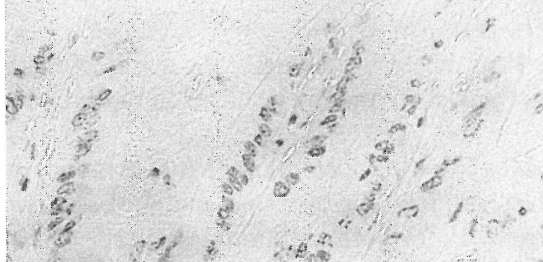




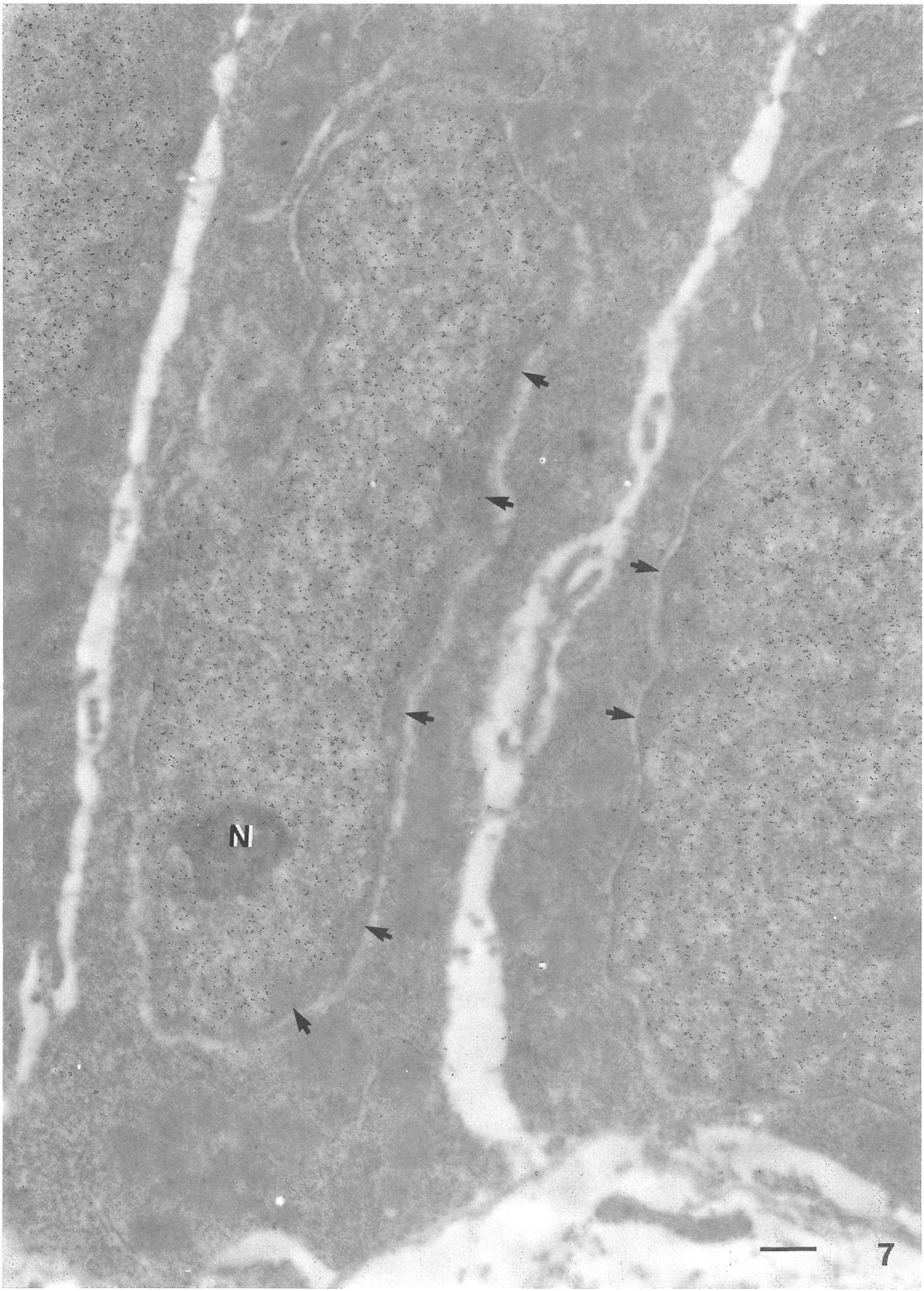

Fig. 7. Electron micrograph of cells situated at the bottom of a rat small intestinal crypt immunostained for ProT. The gold particles are located in the nucleus, the cytoplasm being negative. Within the nuclei immunolabelling is primarily located in the euchromatin; note that the heterochromatin associated with the nuclear membrane (arrows) lacks of gold particles. Nucleolus $(\mathrm{N})$ was essentially negative and only pars amorpha, that represents large loops of DNA, shows occasional gold granules. $\times 26600$, Bar $=1 \mu \mathrm{m}$. 


\section{References}

1. Burns, E. R., Scheving, L. E., Fawcett, D. F., Gibbs, W. M. and Galatzan, R. E.: Circadian influence on the frequency of labeled mitoses method in the stratified squamous epithelium of the mouse esophagus and tongue. Anat. Rec. 184; 265-274, 1976.

2. Conteas, C., Mutchnick, M., Palmer, K. C., Weller, K. C., Luk, G. D., Naylor, P. H., Erdos, M. R., Goldstein, A. L., Pannerselvam, C. and Horecker, B. L.: Cellular events of thymosin immunoreactive peptides are linked to proliferative events: Evidence for a nuclear site of action. Proc. Nat. Acad. Sci. USA 87; 3269-3273, 1990.

3. Dalakas, M., Engel, W. K., McClure, J. E., Goldstein, A. L. and Askanas, V. J.: Immunocytochemical localization of thymosin alpha1 in thymic epithelial cells of normal and myastenia gravis patients and in thymic cultures. J. Neurol. Sci. 50; 239-247, 1981.

4. Dominguez, F., Magdalena, C., Cancio, E., Roson, E., Paredes, J., Loidi, L., Zalvide, J., Fraga, M., Forteza, J., Regueiro, B. and Puente, J.: Tissue concentrations of prothymosin alpha: a novel proliferation index of primary breast cancer. Eur. J. Cancer 29A; 893-897, 1993.

5. Dosil, M., Freire, M. and Gomez-Marquez, J.: Tissue specific and differential expression of prothymosin alpha gene during rat development. FEBS Lett. 269; 373-376, 1990.

6. Economou, M., Seferiadis, K., Frangou-Lazaridis, M., Horecker, B. L. and Tsolas, O.: Isolation and partial characterization of prothymosin alpha from porcine tissues. FEBS Lett. 233; 342-346, 1988.

7. Eilers, M., Schirm, S. and Bishop, J. M.: The MYC protein activates transcription of the alpha prothymosin gene. $E M B O$ J. 10; 133-141, 1991.

8. Eschenfeldt, W. H. and Berger, S. L.: The human prothymosin alpha gene is polymorphic and induced upon growth stimulation: evidence using a cloned cDNA. Proc. Natl. Acad. Sci. USA 83; 9403-9407, 1986.

9. Fraga, M., Garcia-Caballero, T., Dominguez, F., PerezBecerra, E., Beiras, A. and Forteza, J.: Immunohistochemical location of prothymosin alpha in regenerating human hepatocytes and hepatocellular carcinomas. Virchows Arch. [A] 423; 449-452, 1993.

10. Frillingos, S. and Tsolas, O.: Age-related and sex-related differences in the content of prothymosin alpha in rat tissues. Experientia 48; 236-239, 1992.

11. Gallego, R., Roson, E., Garcia-Caballero, T., Fraga, M., Forteza, J., Dominguez, F. and Beiras, A.: Prothymosin alpha expression in lymph nodes and tonsils: An optical and ultrastructural study. Acta Anat. 143; 219-222, 1992.

12. Garcia-Caballero, T., Dominguez, F., Roson, E., Gallego, R., Zalvide, J., Forteza, J. and Beiras, A.: Distribution of prothymosin alpha in rat and human adrenal cortex. Anat. Rec. 239; 88-94, 1994.

13. Gaubatz, S., Meichle, A. and Eilers, M.: An E-Box element localized in the first intron mediates regulation of prothymosin $\alpha$ gene by c-myc. Mol. Cell Biol. 14; 3853-3862, 1994.

14. Gratzner, H. G.: Monoclonal antibody to 5-bromo and 5iododeoxyuridine. Science 218; 474-475, 1982.

15. Hall, P. A. and Woods, A. L.: Immunohistochemical markers of cellular proliferation: achievements, problems and prospects. Cell Tissue Kinet. 23; 505-522, 1990.

16. Hall, P. A., Levison, D. A., Woods, A. L., Yu, C. C. W., Kellock, D. B., Watkins, J. A., Barnes, D. M., Gillet, C. E., Camplejohn, R., Dover, R., Waseem, N. H. and Lane, D. P.: Proliferating cell nuclear antigen (PCNA) immunolocalization in paraffin sections: an index of cell proliferation with evidence of deregulated expression in some neoplasms. J. Pathol. 162; 285-294, 1990.

17. Haritos, A. A., Goodall, G. and Horecker, B. L.: Prothymosin alpha: isolation and properties of the major immunoreactive form of thymosin alpha 1 in rat thymus. Proc. Natl. Acad. Sci. USA 81; 1008-1011, 1984.

18. Haritos, A. A., Tsolas, O. and Horecker, B. L.: Distribution of prothymosin alpha in rat tissues. Proc. Natl. Acad. Sci. USA 81; 1391-1393, 1984.

19. Hsu, S. M., Raine, L. and Fanger, H.: The use of avidinbiotin-peroxidase complex $(\mathrm{ABC})$ in immunoperoxidase techniques: a comparison between $\mathrm{ABC}$ and unlabelled antibody (PAP) procedures. J. Histochem. Cytochem. 29; 577-580, 1981.

20. Lee, C. S.: Differences in cell proliferation and prognostic significance of proliferating cell nuclear antigen and Ki-67 antigen immunoreactivity in in situ and invasive carcinomas of the extrahepatic biliary tract. Cancer 78; 1881-1887, 1996.

21. Low, T. L. K., Thurman, G. B., Chincarini, C., Mcc Lure, J., Marshall, G. D., Hu, S. K. and Goldstein, A. L.: Current status of thymosin research: evidence for the existence of a family of thymic factors that control T-cell maturation. Ann. N.Y. Acad. Sci. 332; 33-48, 1979.

22. Mori, M., Barnard, G. F., Staniunas, R. J., Jessup, J. M., Steele, G. D. Jr. and Chen, L. -B.: Prothymosin mRNA expression correlates with that of c-myc in human colon cancer. Oncogene 8; 2821-2826, 1993.

23. Roson, E., Garcia-Caballero, T., Heimer, E. P., Felix, A. M. and Dominguez, F.: Cellular distribution of prothymosin alpha and parathymosin in rat thymus and spleen. J. Histochem. Cytochem. 38; 1889-1894, 1990.

24. Roson, E., Gallego, R., Garcia-Caballero, T., Heimer, E. P., Felix, A. M. and Dominguez, F.: Prothymosin alpha expression is associated to cell division in rat testis. Histochemistry 94; 597-599, 1990.

25. Roson, E., Gallego, R., Garcia-Caballero, T., Fraga, M., Dominguez, F. and Beiras, A.: Evolution of prothymosin alpha and proliferating cell nuclear antigen (PCNA) immunoreactivity through the development of rat ovarian follicles. Histochem. J. 25; 497-501, 1993.

26. Sarraf, C. E., Mcc Ormick, C.S. F., Brown, G. R., Price, Y. E., Hall, P. A., Lane, D. P. and Alison, M. R.: Proliferating cell nuclear antigen immunolocalization in gastrointestinal epithelia. Digestion 50; 85-91, 1991.

27. Sburlati, A. R., Manrow, R. E. and Berger, S. L.: Prothymosin-alpha antisense oligomers inhibit myeloma cell division. Proc. Natl. Acad. Sci. USA 88; 253-257, 1991.

28. Shiina, H., Igawa, M., Nagami, N., Yagi, H., Urakami, S., Yoneda, T., Shirakawa, H., Ishibe, T. and Kawanishi, M.: Immunohistochemical analysis of proliferating cell nuclear antigen, p53 protein and $\mathrm{nm} 23$ protein, and nuclear DNA content in transitionalcell carcinoma of the bladder. Cancer 78; 17621774, 1996.

29. Tsitsiloni, O.E., Stiakakis, J., Koutselinis, A., Gogas, J., Markopoulos, C., Yialouris, P., Bekris, S., Panoussopoulos, D., Kiortsis, V., Voelter, W. and Haritos, A. A.: Expression of $\alpha$-thymosins in human tissues in normal and abnormal growth. Proc. Natl. Acad. Sci. USA 90; 9504-9507, 1993.

30. Vareli, K., Frangou-Lazaridis, M. and Tsolas, O.: Prothymo$\sin \alpha$ mRNA levels vay with c-myc expression during tissue proliferation, viral infection and heat shock. FEBS Lett. 371; 337-340, 1995.

31. Vareli, K., Tsolas, O. and Frangou-Lazaridis, M.: Regulation of prothymosin $\alpha$ during the cell cycle. Eur. J. Biochem. 238; 799-806, 1996.

32. Wolf, H. K. and Dittrich, K. L.: Detection of proliferating cell 
nuclear antigen in diagnostic histopathology. J. Histochem. Cytochem. 40; 1269-1273, 1992.

33. Wu, C. G., Hakvoort, T. B., Lammers, W. H. and Chamuleau, R. A.: Isolation of an up- and down regulated cDNAs associated with hepatocellular carcinoma by a substractionenhanced display technique. Biochim. Biophys. Acta 1315;
169-175, 1996.

34. Zalvide, J. B., Cancio, E., Alvarez, C. V., Regueiro, B. J. and Dominguez, F.: Prothymosin $\alpha$ mRNA levels are invariant throughout the cell cycle. J. Biol. Chem. 267; 8692-8695, 1992.

35. Zatz, M. M. and Goldstein, A. L.: Thymosins, lymphokines, and the immunology of aging. Gerontology 31; 263-277, 1985. 